\title{
Development of Science E-Flipbook Integrated Illegal Sand Mining on River Basin to Improve Environmental Care Attitude
}

\author{
Shobhi Al-Ghifari Azhary ${ }^{1}$, I Gusti Putu Suryadarma ${ }^{2}$, \\ Puspa Indah Devitasari ${ }^{3}$, Kuswanto ${ }^{4}$ \\ ${ }^{1,2,3}$ Natural Science Education, Yogyakarta State University, Indonesia \\ ${ }^{4}$ General Education, Central Luzon State University, Philippines \\ shobhialghifari.2018@student.uny.ac.id,samodhaya@yahoo.com, \\ pidevitasari@gmail.com, kuswanto@clsu.edu.ph
}

\begin{abstract}
Keyword:

E-flipbook;

Science;

Water pollution;

Illegal sand mining;

River basin.

The aim of this research is to produce a valid e-flipbook on science learning content for water pollution that integrated with illegal sand mining activities in a river basin to enhance environmental care attitude. The research method used was research and development with ADDIE models that are limited to the developing stage. The research sample consisted of 20 seventh grade students of junior high school. The average validation resulted by media expert is 3,5 and content expert is 3,6 with very good category, the result of validation by science teacher is on average 3,6 with very good category and peer reviewer obtained an average value of 3,7 with very good category, the results of validation by 20 students obtained an average value of 3,7 with very good categories. Research data were analyzed and interpreted using descriptive analysis. Based on the results of development and validation, this e-flipbook can be concluded valid and can be applied in learning. This research is important because it uses technology and raises issues about environmental problems.
\end{abstract}

Article History:

Received: $30-01-2020$

Revised : 10-03-2020

Accepted: 10-04-2020

Online : 11-04-2020

\author{
This is an open access article under theCC-BY-SA license \\ $\Rightarrow$ crossret \\ https://doi.org/10.31764/ijeca.v3i1.2036
}

\section{A. INTRODUCTION}

Sciences are subjects studied at primary and secondary school levels. Science learning is a study that examines natural phenomena. Learning of science is based on principles, a process that can foster the scientific attitudes of students to the concepts of science. Science subjects contain materials that explain how nature works so that students can understand the natural events found in the surrounding environment. These natural phenomena are then compiled systematically in the teaching materials that are then applied in the school.

The teaching materials used in science learning from time to time continue to change to suit the student's condition and progress of the age. The teaching materials underwent a significant change in the presence of digital technology, where the teaching materials were originally presented in the form of a package book has evolved with the presentation of learning materials in digital form. Both types of teaching materials are still in use today. This can be seen from the 
distribution of printed books and also the creation of e-books that can be downloaded from the official website of the Indonesian Ministry of Education.

The use of printed and electronic teaching materials has its own advantages. Printed materials are not limited to the presence or absence of electricity. It is suitable for use in areas that have not yet been electric. While electronic teaching materials have an efficient place advantage, because it is only a digital application and on materials can be inserted animations and video learning. Electronic teaching materials are suitable for use in areas that have electricity and have the right electronic media access. The use of both teaching materials will be effective if the use is in accordance with the situation and technological developments. In addition to the shape of teaching materials, science learning is also developed from the other side such as learning content.

Science learning content is based on phenomena that occur in the surrounding environment according to the level of students ' ability in understanding learning. Learning content in teaching materials is a study of natural phenomena that are generally and few are integrated directly in specific natural events such as natural disasters, local wisdom, local potentials, and indigeneous and community activity in a region. Mapping of learning materials integrated with the environment also began to be conducted such as mapping local potentials to learning (Basuki, Jufrida, \& Suryanti, 2019; Jufrida, Basuki, \& Pratiwi, 2019). Learning by integrating directly with environmental conditions can improve student learning outcomes such as understanding Student Concepts (Tamimiya \& Suryadarma, 2019), Creative Thinking Skills (Siti Sriyati, Wahyu Rimbun, 2019) and Environmental Care attitudes (Marlina, Hardigaluh, \& Yokhebed, 2015). Examples of the integration of science materials with the environment of students is the illegal sand mining activities that occur in the river basin area Batanghari in Jambi that can pollute the water environment.

Sand mining has a social impact and environmental impact. Social impacts such as noise from diesel engines and sand-impair truck fumes (Kuspriyanto, 2016), while its environmental impacts are accelerating the river erosion rate (Suherman, Suryaningtyas, \& Mulatsih, 2015) and making water quality Poor and increases water temperature (Rizqan, Mahyudin, Rahman, \& Hadie, 2016). The knowledge of water pollution from illegal sand mining activities can be given to students by integrating it into the learning materials presented in the appropriate teaching materials. This learning integration aims to make learning contextual and fast to understand because students can directly learn the events of the nature that they experienced and witnessed.

The development of teaching materials integrated environmental issues must be precise and efficient so as to provide maximum learning outcomes in students. Electronic teaching materials are the right materials because they maximize animation and video features. The electronic learning materials must contain not only text, but also elements that are able to draw attention to important terms and also continue to motivate the students and preserve their attention with images, videos, sound recordings etc. (Klement, Dostál, \& Marešová, 2014). One example of an electronic teaching material that has animation and video features is the e-flipbook. E-flipbook is an electronic-shaped flipbook in digital media created using computer software.

Based on the excellence in electronic teaching materials that contain the learning material of environmental pollution that integrated the activity of illegal sand mining in the river basin, then can be done research of development science e-flipbook study Environmental pollution material, especially water environment integrated illegal sand mining activities on the river basin. This research aims to produce a valid e-flipbook that can be used as a teaching material at the school or self-teaching materials of students at home. 


\section{B. METHODS}

This research uses the research and development (R\&D) method. The development Model used is ADDIE but is limited to the develop stage. The steps in this study are: (1) Analysis. The stage of analysis is a step to know the needs and information of product development according to the characteristics of learners, learning environment, learning content and the prevailing curriculum; (2) Design. Design stage is done to produce product development guidelines and research instrument grating; (3) Develop. Development stage is done to produce a valid product. Product revision based on expert assessment, IPA teacher, colleague and product limited trial. The development phase consists of several activities: (a) initial product development, (b) development of research instruments, (c) initial product feasibility assessment, (d) validation instrument assessment, (e) First revision of product, (f) limited product trials, and (g) further revision of the product.

This study was conducted in Junior High School 5 Merlung, West Tanjung Jabung Regency, Jambi in odd semester 2019/2020. The sample in this study amounted to 20 students and the population of all learners of Grade 7 odd semester. Students who are the subject of research will be given a product developed, then assess the product.

The assessment instrument in the study was a validation sheet of material and media experts, a science teacher's assessment sheet and peer-reviewed companion and a student readability questionnaire. The instrument used is a Likert-scale poll. The Data obtained from the research was then analyzed using descriptive analysis to determine the feasibility of the research and product instruments. The steps to descriptive analysis are (1) Calculating the average rating score using the equation:

$$
\bar{X}=\frac{\sum x}{n}
$$

Where $\bar{X}=$ mean (average), $\sum x=$ number of scores, and $n=$ amount of data; (2) Finding the ideal mean $\bar{X}_{l}$ and standard deviation (SBi) by:

$$
\begin{aligned}
& \bar{X}_{l}=1 / 2(\text { ideal maximum score }+ \text { ideal minimum score) } \\
& \mathrm{SBi}=1 / 6 \text { (ideal maximum score }- \text { ideal minimum score); }
\end{aligned}
$$

(3) Convert scores into values with the following criteria and compare them with the results of the assessment obtained.

Table 1. Assessment Categories

\begin{tabular}{cc}
\hline Respondents Score & Categories \\
\hline$X \geq \bar{X}_{i}+1.0 S B i$ & Very Good \\
\hline $\bar{X}_{i}+1.0 S B i>X \geq \bar{X}_{i}$ & Good \\
\hline $\bar{X}_{i}>X \geq \bar{X}_{i}-1.0 S B i$ & Bad \\
\hline$X<\bar{X}_{i}-1.0 S B i$ & Very Bad \\
\hline \multicolumn{2}{c}{ (Mardapi, 2012) }
\end{tabular}




\section{RESULT AND DISCUSSION}

This research resulted in the final product in the form of science e-flipbook environmental pollution learning content that integrated the activity of illegal sand mining on the river basin to improve the caring environment of the students. Each development stage provides results in the form of:

\section{Analysis}

Analysis stage generates information data from students, teachers and school observations of the needs of the product. From this analysis it is noted that schools where research has used technology in learning, such as the use of LCD projectors but their use is still limited to displaying learning videos and power point slides. The learning contents are still dominated by printed books and their content has not been specifically integrated in the environmental issues. As for the learning that has been passed, students have been taught using laptops and smartphones in the learning process but the use is still limited, this is because some things like school do not have their own computer labs so as to utilize laptops and smart-phone students and teachers. Such learning is used in learning contents that are felt to be difficult to explain only with books. Teachers who teach science at school conduct learning based on the curriculum that is available at school by utilizing the teaching resources and learning media. Science teachers in school have been prepared to utilize digital in-school learning, this is evidenced by a certificate of digital-based learning training obtained by teachers.

\section{Design}

The design phase results in product development guidelines and research instrument grating. Development guidelines are used as a reference for product development and valuation. The Product development guidelines contain (a) development objectives, i.e. development aims to produce electronic teaching materials in the form of a valid e-flipbook and can be used as teaching materials at school or at home (b) learning content, which is material about environmental pollution focused on subchapter pollution of water environment, where the learning content is integrated with illegal sand mining activities in the river basin, is the thing that will be the identifier of the e-flipbook developed where in this case the e-flipbook is a software application with the extension. exe, integrated into the environment, as well as loading images and videos of the feasibility (d) eligibility criteriaswhich are the aspects assessed in the e-flipbook of material aspects and media (e) storyboard which is an overview of the layout of the placement of learning contentss, images, videos and other important aspects of the e-flipbook. While the instrument grille is used for the reference of research instrument creation, these grids consist of assessed aspects, scoring criteria and the given score requirements.

\section{Development}

The development stage resulted in an e-flipbook and a research instrument for media and material validation sheets, science teachers ' assessment sheets, educational and peer friends, student readability polls that have been validated on limited trials and products The revised one. The results of the validity of (a) the average value of the media expert amounted to 3.5 with very good category, (b) content expert with an average of 3.6 with a very good category, (c) The value of science teacher with an average of 3.6 very good category, (d) Assessment of peer reviewer an average of 3.7 with very good category, as well as (e) The results of the students with averages of 3.7 and very good categories. This assessment category is based on the following Table 2 which refers to Table 1. 
Table 2. Assessment Range Score Categories

\begin{tabular}{cc}
\hline Respondents Range Score & Categories \\
\hline $3,0-4,0$ & Very Good \\
\hline $2,5-2,9$ & Good \\
\hline $2,0-2,4$ & Bad \\
\hline $0,0-1,9$ & Very Bad \\
\hline
\end{tabular}

\section{CONCLUSION AND SUGGESTIONS}

Development of e-flipbook science integrated the activity of illegal sand mining in the river basin produces a valid product of both the expert, science teachers, associates and learners. This e-flipbook can be used in Grade 7 science learning on environmental pollution material in subchapters of water pollution. The advantage of this e-flipbook is that it has been utilizing technology in learning and integrating concepts of learning with environmental issues, so contextual learning occurs. This e-flipbook is expected to be used as a teaching material and is able to improve the knowledge and caring environment of the students. As a continuation of this study, there is a continued study of the effectiveness of this e-flipbook use in learning so that it is more beneficial.

\section{REFERENCES}

Basuki, F. R., Jufrida, \& Suryanti, K. (2019). Identification of Potential Local Wisdom of Senamat Ulu Village (Electrical Independent Village) as a Source of Science Learning. Journal of Physics: Conference Series, 1185(1). https://doi.org/10.1088/1742-6596/1185/1/012102

Jufrida, Basuki, F. R., \& Pratiwi, D. R. (2019). The Potential of Local Wisdom on Traditional Fishing (Tangkul) Gear in Lake Sipin Jambi City as a Science Learning Source. Scientiae Educatia: Jurnal Pendidikan Sains, $7(2), \quad 146-158$. https://doi.org/10.24235/sc.educatia.v7i2.2858

Klement, M., Dostál, J., \& Marešová, H. (2014). Elements of Electronic Teaching Materials with Respect to Student's Cognitive Learning Styles. Procedia - Social and Behavioral Sciences, 112, 437-446. https://doi.org/10.1016/j.sbspro.2014.01.1186

Kuspriyanto. (2016). Dampak Penambangan Galian C (Pasir) Di Pinggiran Sungai Brantas Kecamatan Ngunut Kabupaten Tulungagung. Swara Bhumi, 3(3), 202-213.

Mardapi, D. (2012). Pengukuran, Penilaian \& Evaluasi Pendidikan. Yogyakarta: Nuha Litera.

Marlina, R., Hardigaluh, B., \& Yokhebed, M. (2015). Pengembangan Modul Pengetahuan Lingkungan Berbasis Potensi Lokal Untuk Menumbuhkan Sikap Peduli Lingkungan Mahasiswa Pendidikan Biologi. Jurnal Pengajaran Matematika Dan Ilmu Pengetahuan Alam, 20(1), 94-99. https://doi.org/10.18269/jpmipa.v20i1.569

Rizqan, A., Mahyudin, I., Rahman, M., \& Hadie, J. (2016). Status Kualitas Air Sungai Sekitar Kawasan Penambangan Pasir Di Sungai Batang Alai Desa Wawai Kalimantan Selatan. EnviroScienteae, 12(1), 1. https://doi.org/10.20527/es.v12i1.1094

Siti Sriyati, Wahyu Rimbun, A. (2019). Penerapan Bahan Ajar Berbasis Potensi Lokal Ekosistem Mangrove Pondok Bali untuk Meningkatkan Kemampuan Berpikir Kreatif. Edusains, 11(1), 105-111. https://doi.org/http://doi.org/10.15408/es.v11i1.11664

Suherman, D. W., Suryaningtyas, D. T., \& Mulatsih, S. (2015). Dampak Penambangan Pasir Terhadap Kondisi Lahan dan Air di Kecamatan Sukaratu Kabupaten Tasikmalaya. Jurnal Pengelolaan Sumberdaya Alam Dan Lingkungan, 5(2), 99-105. https://doi.org/10.19081/jpsl.5.2.99

Tamimiya, K. T., \& Suryadarma, I. G. P. (2019). Potensi Lokal Gunung Ijen untuk Pemahaman Konsep dan Berpikir Kreatif Pengurangan Resiko Bencana. Jurnal Inovasi Pendidikan, 5(1), 117-128. https://doi.org/https://doi.org/10.21831/jipi.v5i1.25702 